2017-05-16

\title{
Knowledge of Food Safety and Food Handling Practices amongst Food Handlers in the Republic of Ireland
}

\author{
Nora A. Moreb \\ Anushree Priyadarshini \\ Technological University Dublin, anushree.priyadarshini@tudublin.ie \\ Amit Jaiswal \\ Technological University Dublin, amit.jaiswal@tudublin.ie
}

Follow this and additional works at: https://arrow.tudublin.ie/schfsehart

Part of the Food Microbiology Commons, and the Other Food Science Commons

\section{Recommended Citation}

Nora M. A., Priyadarshini, A. \& Jaiswal, A.K. (2017). Knowledge of food safety and food handling practices amongst food handlers in the Republic of Ireland. Food Control. doi:10.1016/j.foodcont.2017.05.020

This Article is brought to you for free and open access by the School of Food Science and Environmental Health at ARROW@TU Dublin. It has been accepted for inclusion in Articles by an authorized administrator of ARROW@TU Dublin. For more information, please contact arrow.admin@tudublin.ie, aisling.coyne@tudublin.ie, gerard.connolly@tudublin.ie.

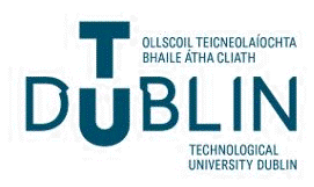




\section{Accepted Manuscript}

Knowledge of Food Safety and Food Handling Practices amongst Food Handlers in the Republic of Ireland

Nora A. Moreb, Anushree Priyadarshini, Amit K. Jaiswal

\begin{tabular}{|c|c|}
\hline$=$ & $\begin{array}{l}\text { CONTROL } \\
\text { CONTROL }\end{array}$ \\
\hline 한 & $\begin{array}{l}\text { CONTROL } \\
\text { CONTROL } \\
\text { CONTROL } \\
\text { CONTROL }\end{array}$ \\
\hline & $\begin{array}{l}\text { CONTROL } \\
\text { CONTROL }\end{array}$ \\
\hline
\end{tabular}

PII: $\quad$ S0956-7135(17)30263-3

DOI: $\quad$ 10.1016/j.foodcont.2017.05.020

Reference: $\quad$ JFCO 5626

To appear in: $\quad$ Food Control

Received Date: $\quad 29$ March 2017

Revised Date: $\quad 14$ May 2017

Accepted Date: $\quad 15$ May 2017

Please cite this article as: Nora A. Moreb, Anushree Priyadarshini, Amit K. Jaiswal, Knowledge of Food Safety and Food Handling Practices amongst Food Handlers in the Republic of Ireland, Food Control (2017), doi: 10.1016/j.foodcont.2017.05.020

This is a PDF file of an unedited manuscript that has been accepted for publication. As a service to our customers we are providing this early version of the manuscript. The manuscript will undergo copyediting, typesetting, and review of the resulting proof before it is published in its final form. Please note that during the production process errors may be discovered which could affect the content, and all legal disclaimers that apply to the journal pertain. 


\section{Highlights}

- Food safety knowledge amongst Irish residents was explored.

- 1069 participants from across Ireland contributed to the study.

- Knowledge of food handling and food poisoning observed was critically low.

- Gender, age, place of residence and education level impacted the knowledge level.

- Per capita income had no influence on the knowledge level. 
1 Knowledge of Food Safety and Food Handling Practices amongst Food Handlers in the

\section{Republic of Ireland}

3 Nora A. Moreb $^{1}$, Anushree Priyadarshini ${ }^{2}$, and Amit K. Jaiswal ${ }^{1}$

$4 \quad{ }^{1}$ School of Food Science and Environmental Health, College of Sciences and Health, Dublin

5 Institute of Technology, Cathal Brugha Street, Dublin 1, Republic of Ireland.

$6 \quad{ }^{2}$ School of Business, University College of Dublin, Belfield, Dublin 4, Republic of Ireland.

7

8

9

10

11

12

13

14

15

16

17

*Corresponding author:

18 Email: anushree.priyadarshini@ucd.ie (A. Priyadarshini)

19

Tel: +35317165411

21 Abstract 
22 Food safety concerns have existed for a long time, as millions of people across the globe

23 suffer from food borne disease every year. Contamination of food owing to limited

24 knowledge of food safety practices primarily increases the risk of food borne illnesses. In the

25 present study, quantitative research was carried out to gauge the level of food safety

26 knowledge amongst people living in Ireland. A total of 1069 participants from all over the

27 Republic of Ireland contributed to the survey (of which 821 were included in this research).

28 Results showed that the residents of Ireland overall had an average level on knowledge of

29 food safety practices $(67.0 \%$ passing rate). They had an average level of knowledge in food

30 storage (52.8\% passing rate), usage and maintenance of the kitchen facilities (59.0\% passing

31 rate), and personal hygiene (61.0\% passing rate). Conversely, they had a critically low level

32 of knowledge in food handling ( $10.8 \%$ passing rate) and food poisoning (20.1\% passing rate).

33 The results of the present study also showed that, the level of knowledge of food safety

34 practices varies amongst the residents based upon their gender, age, place of residence,

35 education level, and marital status, while no significant difference in the knowledge level was

36 observed based upon their per capita income. The study thus, highlights that there is scope for

37 improvement for the residents to advance their knowledge of food safety practices. Therefore,

38 it can be recommended that researchers, educators, food safety communicators, and the

39 media can engage in educating the population, to help the residents advance their food safety

40 knowledge to safer food practices.

43 Keywords: Food safety; Food handling; Food hygiene; ; Knowledge; Practice 


\section{$1 \quad$ Introduction}

46 Foodborne illnesses are a burden globally to public health and to a nation's economy

47 (Copenhagen, 2015; Young, \& Waddell, 2016). In the Republic of Ireland, the numbers of foodborne cases have been rising for the fifth consecutive year in 2015 according to data collected nationally as part of the EU Zoonoses regulation (Health Protection Surveillance Center [HPSC], 2016). Vulnerable groups are the most exposed to the risks of foodborne illnesses (World Health Organization [WHO], 2015a \& WHO, 2014), because their immune systems are not fully capable of fighting off infections (Food and Drug Administration [FDA], 2016a \& FoodSafety.org). A large percentage of the population in Ireland can be categorised as vulnerable, with older adults " 65 years old and older" and younger children of "14 years old and younger" (13.38\% and $22.24 \%$, respectively), compared to the general population (Central Statistics Office [CSO], 2016) increasing the risk of foodborne incidents.

Research has shown that the increase in foodborne illnesses could be linked to improper food safety practices in homes, as home environments can harbour an array of foodborne pathogens (Langiano et al., 2012; Mountjoy, 2014; Young \& Waddell, 2016), such as bacteria, viruses and fungi (Byrd-Bredbenner et al., 2013; National Health Services [NHS], 2014). Furthermore, due to home kitchen being used as a "multipurpose area" for more than just food preparation; this increases the risk of food contamination, proliferation, and possible foodborne illnesses (Byrd-Bredbenner et al., 2013 \& NHS, 2014). According to WHO, Campylobacter, Salmonella and E. Coli are the most common foodborne pathogens that affect millions in the world (WHO, 2015b), including in the Republic of Ireland (HPSC, 2016). While prior research shows that improper handling, preparation, and storage of food can cause foodborne illness (USDA, 2016a), evidences support that in most cases, proper cooking or processing can eliminate the risk of foodborne illnesses (USDA, 2013). The most common source of food in Ireland are home cooked meals made from scratch using fresh 
70

71

72

ingredients increasing the importance of being vigilant about knowledge of food safety practices (Healthy Ireland Survey, 2015).

Recent studies have investigated people's knowledge of food safety in many countries around the world, while in Ireland in 2001, a study was conducted testing the pathogenic foodborne bacteria in domestic kitchens within 25 homes. A total of 325 sampling sites, which included sampling before and after preparing chicken and six sites around the house, results showed that contamination was still found after the preparation of meals, increasing the need for consumer awareness and knowledge in food handling and hygiene (Gorman et al., 2002). Another study that was conducted in Ireland was in 2005, the study was to test the knowledge of 1025 participants from the Irish residents using a questionnaire, the findings of the research is that the majority of the Irish residents have a good base of food safety knowledge, however, that did not translate to the adherence to food safety practices, and knowledge on food poisoning was at a low level (McCarthy et al, 2007). Lastly, in Ireland in 2006 a study that tested the knowledge of food safety amongst 200 of chefs and catering manager was conducted through face to face interviews, the results showed that although they were aware of basic knowledge in order to deliver safe food that followed the law, they still needed extra training to further their knowledge to implement food safety effectively (Bolton et al., 2008). While the number of foodborne incidents are still increasing (HPSC, 2016), current studies to assess the public's knowledge in the Republic of Ireland does not exist.

Therefore, the aim of this study is to contribute to the existing knowledge to tackle the reasoning behind the increasing foodborne incidents by giving an updated insight on the assessment of knowledge of people living in the Republic of Ireland on food safety and their practices on preparing food at home. The study will compare demographics based on their level of knowledge of food safety practices and also to determine common areas of weakness. 
94 This research can help practitioners and researchers in identifying the areas of weakness of

95 the residents for furthering research in the areas needed. It can also aid the educators, food

96 safety policy makers and food safety communicators on where the knowledge is lacking in

97 the Irish residents. The study will achieve the objective by surveying the residents in multiple

98 regions and analysing and comparing the results.

992 Materials and Methods

$100 \quad 2.1 \quad$ Questionnaire Design

101 A questionnaire was designed with multiple-choice questions to survey the public in the

102 Republic of Ireland for their knowledge of food safety practices. It follows a validated 103 questionnaire (Gong et al., 2016) developed and used for conducting similar studies.

104 Appropriate modifications were made to the questionnaire to fit the popular habits and

105 traditions of consumers in Ireland. It was also simplified to make it easier for the participant

106 to answer, as according to McLeod (2014), questionnaires should be simple and easy for the

107 surveyor to understand and aimed to address the concerns of the research.

108 The questionnaire comprised of 32 multiple-choice questions. It was divided into two

109 sections. The first section consisted of six questions that covered the demographics of the

110 individuals being surveyed, such as gender, age, place of residence, per capita annual income

111 (in Euros), educational level and marital status. The second section tested their knowledge of

112 food safety handling in domestic kitchens, which consisted of 26 questions with a total of five

113 subsections that tested knowledge of food storage with six questions, knowledge of food

114 handling via four questions, knowledge of the usage and maintenance of kitchen facilities

115 through six questions, knowledge of personal hygiene with five questions and knowledge of

116 food poisoning via five questions. Once the design of the questionnaire was established, it

117 was pilot-tested amongst food safety and business management professionals to ensure 
118 accuracy, and adjustments were made to enhance the survey based on the feedback received.

\section{$119 \quad 2.2 \quad$ Target Participants}

120 The target participants of the study were the people that reside in the Republic of Ireland,

121 with the restrictions that they were over the age of 18, speak English in order to understand

122 the survey, and handle food in their domestic kitchen to test their knowledge of food safety

123 practices.

\section{$124 \quad$ 2.3 Data Collection}

125 McLeod (2014) highlights that surveys are a useful tool to obtain a high volume of

126 information from a large number of people in an efficient way and in a short period of time.

127 In order to assure coverage in multiple areas on the Republic of Ireland, a survey was

128 conducted across the Republic of Ireland. The participants were selected at random and were

129 approached both in person with a print version of the survey or an electronic link to the

130 survey was sent out for participation and completion of the survey. The print version was to

131 be returned after it was completed on the spot, while participants who used the electronic link

132 filled either on the spot or later at their own convenience. The participants were explained the

133 objective of the study before completion of the survey, and assurance of their complete

134 confidentiality as per the institution ethical guidelines. Furthermore, to ensure a non-bias sampling in coverage, the sample had a frame that covered the demographic aspects of the survey including: gender, age, place of residents, per capita annual income (in Euro's), educational level, and marital status.

138 The survey was distributed and responses were collected from September to December of 139 2016. On average, the participants spend around 20-30 minutes to complete the survey.

140 Participants were approached in high traffic areas, such as popular streets, buildings, events, 141 gatherings etc. Some of the participants were approached in their own households to get the 
142 older age range and countryside array involved. The participants were contacted in a non-

143 systematic way, a total of 1,069 participants contributed, of which, 248 surveys were

144 dismissed due to incomplete survey or participants selected more than one option per 145 question. Thus, 821 surveys were included in this research.

\section{$146 \quad 2.4 \quad$ Data Analysis}

147 For the data analysis, the software package of SPSS version 20.0 by IBM Corporation was

148 used to statistically analyze all the data collected. There were twenty-six questions; each

149 question answered correctly would award the participant one point and zero for incorrect

150 answers, percentages of correct and incorrect answers for each question was calculated.

151 Additionally, each subsection of the knowledge portion of the survey the participant could

152 receive between four to six points depending on the subsection. The entire knowledge section

153 of the survey as well as each subsection had their mean score and standard deviation

154 analyzed. After calculating correct and incorrect answers for each participant, the participants

155 that answered more than half of the questions on the survey correctly would have attained a

156 pass; furthermore, for each subsection and demographics group the passing rates were also

157 analyzed. If the participants achieved a passing rate of $70.0 \%$ or more, they were considered

158 to have a good level of knowledge, however, if the results showed a passing rate of less than

$15950.0 \%$ that would point towards a poor level of knowledge, with $51.0 \%$ to $69.0 \%$ considered

160 as an average level of knowledge.

161 As the data had a skewed distribution, this suggested that it did not follow normal distribution

162 and thus non-parametric analysis would be the most appropriate method for analyzing the

163 data (Sullivan, 2016). Non-parametric tests (Chi-square $\left(x^{2}\right)$, Manne-Whitney U and

164 Kruskale-Wallis) were used to analyze the entire data. The Chi-square $\left(x^{2}\right)$ test was adopted 
166 whether there was a difference. The Manne-Whitney U test was used to compare the

167 demographics with two independent samples (Sullivan, 2016). Therefore, it was used to

168 compare the difference between city residents and countryside residence with the mean score,

169 and the Kruskale-Wallis test was used to compare the specific demographics of three or more

170 independent samples (Sullivan, 2016). Thus, it was used for the rest of the demographics

171 (gender, age, per capita annual income (in Euros), educational level and marital status), and compared them with the mean scores of the participants

$173 \quad 3 \quad$ Results and Discussion

\section{$174 \quad 3.1 \quad$ Samples Profile}

175 Table 1 presents 6 of the demographic characteristics of the sample. $51.3 \%$ of the respondents 176 were females, $35.2 \%$ were between the ages of 26 and $35,73.3 \%$ were from the city, $59.0 \%$

177 had an annual income of 30,000 euro's or below, which is equivalent to 31,354.5 US dollars 178 by the end of $2016 ; 72.5 \%$ of the respondents had a university education or above, and $55.7 \%$ 179 were unmarried.

\subsection{Knowledge of Food Safety Practices in Domestic Homes in the Republic of}

\section{Ireland}

\section{$182 \quad 3.2 .1 \quad$ Knowledge on Food Storage}

183 Table 2 presents the knowledge of food safety in food storage; there were 6 questions in this subsection to assess their knowledge, resulting in the mean score of 3.5 points (from a range of 0-6). If the respondents got three or more out of this section of questions correctly, they attained a pass. The passing rate for this section in Ireland was at $52.8 \%$, indicating an

187 average degree of knowledge in food storage, which links a higher risk of poor food safety practices with mistakes done with improper food storage practices (Langiano et al., 2012). 
189 The highest pass rate in this subsection was that $78.1 \%$ of the respondents knew that meat

190 should be bought at the end of the shopping time. Moreover, the pass rate for the same

191 question in China was 36.7\% (Gong et al., 2016), in Lebanon 59.7\% (Hassan \&Dimassi, 192 2014), in Greece 55.3\% (Lazou et al., 2012), in Jordan 73.6\% (Osailiet al., 2011), and in the

193 US it was observed $38.5 \%$ did not pick frozen foods or raw meat at the end of shopping time

194 (Yapet al., 2016), highlighting that Irish residents got the highest passing rate among the countries discussed above.

196 However, the lowest knowledge in this subsection is whether or not freezing temperatures

197 would affect bacterial activity, in where Ireland's passing rate was only $28.6 \%$; while in

198 Canada 77.0\% (Courtney et al., 2016), and in China it was 12.4\% (Gong et al., 2016), in

199 Lebanon 64.0\% (Hassan \& Damassi, 2014), in Greece 78.3\% (Lazou et al., 2012), and in

200 Jordan 52.2\% (Osaili et al., 2011), indicating that Ireland is one of the lower passing rate for 201 this question.

\subsubsection{Knowledge on Food Handling}

Table 3 presents the knowledge of food safety in food handling; there were 4 questions in this subsection to assess their knowledge, resulting in a mean score of 2.1 points (from a range of 0-4). The respondents needed to get two questions or more correctly in order to attain a pass in this subsection, which was $10.8 \%$ in Ireland, indicating critically low degree of knowledge.

207 Most respondents in present study (66.1\%) knew that the correct answer on washing vegetables and fruits must be washed with running cold water, while in China $51 \%$ knew the correct answer to this same question (Gong et al., 2016), in Canada 92.5\% knew that fresh

210 produce should be washed with cold running water (Burke et al., 2016), in South Africa 82\%

211 claimed to have washed their fruits and vegetables correctly (Sibanyoni et al., 2016), in

212 Lebanon 51.4\% wash them under running water (Hassan \&Dimassi, 2014), In Greece 72.8\% 
213 knew the correct answer (Lazou et al., 2012), in Saudi Arabia 91.7\% knew the correct answer

214 (Sharif \& Al-Malki, 2010), and in Jordan 28.4\% knew the correct answer (Osaili et al., 2011).

215 Ireland's knowledge is on the lower average of the passing rate although this is the highest

216 knowledge in this subsection.

217 The lowest knowledge in this subsection was regarding thawing of raw meat, $43.5 \%$ of the

218 Irish residents knew that the least safe way to thaw raw meat is on the chopping board, while

219 in China 38.2\% knew the correct answer (Gong et al., 2016), 58.3\% in Brazil knew the best 220 way to defrost food (Uggioni \& Salay, 2012), in the US among the elderly $50.0 \%$ did not

221 thaw their meat in the refrigerator (Yap et al., 2016), while in the US $79.2 \%$ knew that the

222 best way to thaw meat is in the refrigerator and only $1.4 \%$ thought that thawing on the 223 countertop is the best way (Meysenburg et al., 2014), in Lebanon 28.0\% knew to defrost raw 224 meat in the refrigerator while $38.5 \%$ thought that on the countertop is the best way (Hassan \& 225 Dimassi, 2014), in Greece 24.1\% knew the correct answer (Lazou et al., 2012), and in Jordan $22627.1 \%$ knew the correct answer (Osaili et al., 2011). Irish residents in the present study are 227 within the lower knowledge rate of this question.

228 Control measures that are currently in place by producers are not sufficient in eliminating the 229 risk of food borne illness, so precautions taken by the consumer in handling food is critically 230 important as it could avoid cross-contamination, eliminate or slow the growth of existent 231 bacteria, which eventually would avoid foodborne illnesses, making it very important for the 232 consumer to be well informed about proper food handling practices (Langiano et al., 2012; 233 Mountjoy, 2014). Plus, Ireland is alarmingly low in knowledge in this subsection making it 234 essential for the public to be better informed. 
235

236

237

238

239

240

241

242

243

\subsubsection{Knowledge on Usage and Maintenance of Kitchen Facilities}

Table 4 presents the knowledge of food safety on usage and maintenance of kitchen facilities at domestic homes in Ireland; there are 6 questions in this subsection to assess their knowledge, resulting in a mean score of 3.7 points (from a range of $0-6$ ). The respondents needed to get three questions or more correctly in order to attain a pass in this subsection, which was $59.0 \%$ in Ireland, confirming residents had average degree of knowledge.

The highest passing rate in this subsection was that $71.6 \%$ of the respondents knew the correct temperature to store food in the refrigerator, while in China it was $32.4 \%$ (Gong et al., 2016), in Portugal $69.5 \%$ of respondents chose the answer of below or at $2-8^{\circ} \mathrm{C}$ (Carbas et al., 2013), in Wales $84.0 \%$ of the elderly were unaware of the proper temperature of the refrigerator (Evans \& Redmond, 2016), in Lebanon 53.1\% knew the correct answer (Hassan \& Damassi, 2014), in Greece 44.4\% knew the correct answer (Lazou et al., 2012), and in Jordan $34.1 \%$ knew the correct answer (Osaili et al., 2011). Results showed that Ireland is at the higher end of knowledge with regard to this question, and that Irish participants scored highest in this subsection.

On the other hand, the lowest knowledge in this subsection is on the use of the chopping board for raw meat and fresh fruit. $51.2 \%$ of the Irish respondents got the correct answer, while in Canada it was 97.7\% (Burke et al., 2016), in China 12.4\% (Gong et al., 2016), in Brazil 54.0\% (Uggioni \& Salay 2012), 21.0\% among elderly in the US did not use a separate cutting board (Yap et al., 2016), in Lebanon 38.6\% knew the correct answer (Hassan \& Dimassi, 2014), and in Jordan 61.6\% knew the correct answer (Osaili et al., 2011). Survey reveals that Ireland ranks average in where it could be improved.

This subsection is of importance to have knowledge in usage and maintenance of kitchen facilities to avoid pathogenic growth or cross-contamination in order to gain food safety 
259 practice (Evans \& Redmond, 2016; Langiano et al., 2012), including the need to concentrate

260 on hotspots that gather the highest bacterial count based on studies (NHS, 2014), since the

261 Irish consumer has average knowledge, it is clear that the knowledge can and should be

262 improved in order to see decreased incidence of foodborne illnesses.

\subsubsection{Knowledge on Personal Hygiene}

264 Table 5 presents the knowledge of personal hygiene in the Republic of Ireland; there were 5

265 questions in this subsection to assess their knowledge, resulting in a mean score of 3.5 points

266 (from a range of 0-5). The respondents needed to get three questions or more correct in order

267 to attain a pass in this subsection, which was $61.0 \%$ in Ireland, which is an average degree of

268 knowledge.

$85.0 \%$ participants in Ireland that knew to wash their hands with soap and warm water then wipe dry after handling raw meat. While in Canada $66.4 \%$ between the ages of $19-29$ knew the correct answer (Burke, et al., 2016), while 71.5\% of the Canadian undergraduate university students knew how to wash their hands correctly (Courtney et al., 2016), in china 27.2\% (Gong et al., 2016), and in the US 30.8\% in 1998 and $21.5 \%$ in 2010 reported that they did not wash their hands before preparing food showing a decreased curve which indicates improved knowledge over the years and that could be due to several federal media coverage on food safety (Fein et al, 2011), 50.0\% in another study showed that young adults in the US washed their hands properly after handling raw chicken (Byrd-Bredbenner et al., 2009), in another study $91.4 \%$ among the elderly in the US washed their hands properly before preparing food (Yap et al., 2016), while another showed that $45.8 \%$ of the elderly did not

280 know or did not wash their hands properly after handling raw meat (Cates et al., 2009), and in

281 the US $95.8 \%$ of the parents with young children knew to wash their hands before preparing 282 food (Meysenburg, et al., 2014), in South Africa 97.0\% claimed to wash their hands after 
283 handling raw food (Sibanyoni et al., 2016), in Ghana 75.6\% agree that hands should be

284 washed before prepping food (Akonor\&Akonor, 2013), in Greece 57.5\% knew the correct

285 answer (Lazou et al., 2012), and in Saudi Arabia 96.1\% of university students wash their

286 hands before preparing foods (Sharif \& Al-Malki, 2010), 92\% of chefs in Ireland from a

287 previous study knew the correct answer (Bolton et al., 2008). Present study showed that

288 knowledge on when and how to wash hands properly is important and Ireland was on the

289 higher end of the passing rate with knowing both aspects in washing hands after handling raw

290 meats and how to wash it correctly, showing a decent degree of knowledge in personal

291 hygiene.

292 The lowest knowledge in this subsection was related to whether it is safe to handle food as

293 long as gloves are worn. Only 46.3\%Irish participants answered this question correctly. In

294 China, 25.5\% knew the correct answer (Gong et al. 2016); in Brazil, 29.1\% were correct

295 (Uggioni \& Salay 2012); in Greece, 19.6\% chose the correct answer (Lazou et al. 2012);

$29664.0 \%$ of Hispanic families with younger children knew the correct answer (Stenger et al.

297 2014); and, in Jordan, 23.0\% were aware of the correct answer (Osaili et al. 2011). It is

298 evident that, although Irish participants had the poorest level of knowledge in this subsection,

299 they scored at the higher end in terms of knowledge when compared to other countries.

300 However, it is noteworthy that they scored below $50.0 \%$, which is considered a poor degree

301 of knowledge, and there is scope for improvement.

302 According to research, knowledge of the importance of personal hygiene immediately

303 coincides with the adherence to personal hygiene practices (Ismail et al., 2016; Jianu \&

304 Goleţ, 2014), however, research has shown that knowledge on hand hygiene and adherence to

305 the knowledge does not necessarily coincide, which correspondingly needs more attention 306 and stress on its importance (Jianu \& Goleţ, 2014). 


\subsubsection{Knowledge on Food Poisoning}

308 Table 6 presents the knowledge of personal hygiene in the Republic of Ireland; there are 5

309 questions in this subsection to assess this knowledge, resulting in a mean score of 2.4 points

310 (from a range of $0-5$ ). The respondents needed to get three questions or more correctly in

311 order to attain a pass in this subsection, which was $20.1 \%$ in Ireland, which is critically poor

312 degree of knowledge.

313 The highest knowledge in this section was regarding raw or undercooked beef or eggs causing food poisoning and $74.5 \%$ of participants knew the correct answer, this can be easily explained with how recommendations of the Food Safety Authority in Ireland (FSAI) on labelling or serving safely based on the study that showed present pathogens in raw meat and the fact that the European Union (EU) made it mandatory to present safety instructions on cooking raw meat or eggs to avoid food borne illnesses (FSAI, 2013; EC NO 1169/2011); while in China $25.3 \%$ knew undercooked beef, $8.9 \%$ knew raw eggs or $12.2 \%$ knew that both could cause food poisoning (Gong et al., 2016), in Portugal 12.5\% respondents knew that undercooked beef, $19.0 \%$ knew raw eggs, or $43.8 \%$ knew that both including unpasteurized milk could cause food poisoning (Carbas et al., 2013), in South Africa 64.3\% knew that raw eggs could cause food poisoning (Sibanyoni et al., 2016), 44.1\% in Ghana agree that it is safer to eat fully cooked eggs rather than raw (Akonor \& Akonor, 2013), in Saudi Arabia $43.9 \%$ knew that eating raw eggs was not safe while $86.1 \%$ knew that eating under cooked meats is not safe (Sharif \& Al-Malki, 2010), of Hispanic families with young children $35.0 \%$ knew that under cooked eggs can be unsafe and $82.0 \%$ knew that undercooked meat is unsafe

328 (Stenger et al., 2014), and in Jordan 52.9\% knew that undercooked eggs can be unsafe and $79 \%$ knew that undercooked meat is unsafe (Osaili et al., 2011). Ireland though shows decent knowledge in comparison to other countries, yet it is evident from our results that this needs improvements. 
332 The lowest knowledge in this subsection was that $10.1 \%$ of the respondents knew that meat

333 sauce from the deli is most likely to become contaminated with Listeria in comparison to raw

334 or undercooked meat, eggs or vegetables; while in China $24.3 \%$ knew the correct answer

335 (Gong et al., 2016), in Greece it was 15.1\% (Lazou et al., 2012), and only 40\% in the US ever

336 heard of Listeria (Cates et al., 2009). Overall results showed that Ireland has critically poor

337 knowledge in food poisoning.

338 This section is of extreme importance for the Irish residents to understand on how to handle

339 the food to avoid cross contamination and how to cook it properly according to the safety

340 guidelines that are provided by the FDA and USDA in order to avoid food poisoning,

341 moreover, to understand the possible risks of foodborne illnesses if they are to occur (FDA,

342 2016-b\& USDA, 2016-b). An example for this is, in 2015 in Ireland reports showed that one

343 of the most common bacteria is Campylobacter in where 2,451 cases were reported this is the

344 fifth consecutive year to where numbers of cases are elevated; Ireland also had the highest

345 number of cases of verotoxigenic Escherichia coli "E. coli” (VTEC) comparison to Europe

346 where 730 of reported cases and rising every year; 269 cases of Salmonella cases, and 19

347 cases of Listeriosis and rising (HPSC, 2016), if the consumer is eating at home, pathogenic

348 foodborne could be avoided with proper handling using four simple steps, making sure

349 personal and kitchen hygiene is present, separating to avoid cross contamination, cooking

350 each food item to the proper temperature using a thermometer, and chilling promptly (USDA,

351 2016b), and if dining out to assure that the restaurant takes these precautions with hygiene

352 and that the food is fully cooked (Cunningham, 2015). 


\subsection{The Relation between the Demographic Characteristics and Knowledge of Food}

\section{Safety in Homes}

355 There were 5 subsections in total that covered different aspects on food safety knowledge in 356 Ireland, which consisted of 26 questions in total, if the respondent were to get thirteen or 357 more of the overall questions correctly then they have attained a pass, the mean score for the entire survey was 15.3 points (from a rage of 0-26) and a standard deviation of 5.1, with an overall passing rate of $67.0 \%$. Table 7 presents the relation between specific demographic characteristics and mean score and overall passing rate between respondents, using the nonparametric tests (Chi-square $\left(x^{2}\right)$, Manne-Whitney U, and Kruskale-Wallis).

362 The results showed that, gender, age, place of residents, educational level, and marital status

363 with the $(\mathrm{P}<0.05)$ for all five categories showed significant factors that impact the

364 knowledge of food safety practice in the Republic of Ireland, while on the other hand, per capita annual income did not have any significance with the $(\mathrm{P}>0.05)$, which suggests that educators should direct their programs to those 5 factors in order to make an impact on their knowledge level.

Females were better with food safety knowledge with the passing rate of $59.0 \%$, respondents at the age of 26-35 years old were more knowledgeable with a passing rate of $33.0 \%$, people that lived in cities were significantly more knowledgeable with the passing rate of $69.1 \%$, educated people with a university and above degree at $74.2 \%$ passing rate and unmarried were with a passing rate of $53.3 \%$, while married with children and married without children showed significant results in passing rates as $31.1 \%$ and $7.8 \%$ respectively. It is however noteworthy that as the participants were randomly selected, the pass rates of some

375 demographic groups can be very low due to the very small number of respondents in those 376 groups. The findings correlate with a report by WHO in 2015, that "demographic, cultural, 
economic and environmental developments, an ageing population, changing consumer trends and habits, new technologies" all factor increase foodborne health risks (Copenhagen, 2015). Additionally, based on the research findings, it is argued that the aspects that affect food safety practices and knowledge are broad, further education is universally needed in order to help decrease foodborne illnesses and better understand the problem of why food safety is a globally epidemic issue (Copenhagen, 2015).

\section{Conclusion}

384 With the overall passing score of participant being $67.0 \%$ and a mean score of 15.3 points (a range of 0-26), residents of Ireland can be regarded as having an average level of knowledge of food safety practices. Yet, when analysed for the different aspects of the 5 subsections in the survey, their knowledge was found to be critically low in food handling $(10.8 \%$ passing rate) and alarmingly low with regard to the knowledge of food poisoning. Furthermore, the different demographics did show some significant differences, overall women appeared to be more knowledgeable and the eldest (51 years old and above) and youngest (18-25years) groups had the least level of knowledge; people who lived in the city were more knowledgeable than those who lived in the countryside; educated people who had at least a university or above degree knew the most about food safety; and unmarried or married with

394 children had the highest level of knowledge versus those who did not have children and others. Overall, the study indicates that there is scope for improvements about food safety

396 knowledge in people living in Ireland. It is recommended that researchers, educators, food 397 safety communicators, and the media should work towards educating the population to 398 advance their food safety knowledge to safer food practices. 
400 The authors would like to acknowledge the support and facilities provided by Dublin Institute

401 of Technology, Dublin, Ireland. The researcher Nora A. Moreb was financially supported by 402 the Saudi Arabian Government, Saudi Arabia.

\section{Reference}

404 Abbot, J. M., Byrd-Bredbenner, C., Schaffner, D., Bruhn, CM., and Blalock, L., (2009).

405 Comparison of food safety cognitions and self-reported food-handling behaviors with 406 observed food safety behaviors of young adults. European Journal of Clinical $407 \quad$ Nutrition, 63, 572-579.

408 Akonor, P. T. \&Akonor, M.A., (2013). Food Safety Knowledge: The case of domestic food 409 handlers in Accra. European Journal of Food Research \& Review, 3(3), 99.

410 Anderson, A.L., Verrill, L. A. \&Sahyoun, N. R. (2011). Food safety perceptions and practices 411 of older adults. Public Health Reports, 220-227.

412 Bolton, D.J., Meally, A., Blair, I.S., McDowell, D.A. \& Cowan, C. (2008). Food safety 413 knowledge of head chefs and catering managers in Ireland. Food Control, 19(3), 291-300. 414 Burke, T., Young, I., \& Papadopoulos, A. (2016). Assessing food safety knowledge and 415 preferred information sources among 19-29 year olds. Food Control, 69, 83-89.

416 Byrd-Bredbenner, C., Berning, J., Martin-Biggers, J., \& Quick, V. (2013). Food safety in 417 home kitchens: a synthesis of the literature. International Journal of Environmental $418 \quad$ Research and Public Health, 10(9), 4060-4085.

419 Carbas, B., Cardoso, L., \& Coelho, A. C. (2013). Investigation on the knowledge associated 420 with foodborne diseases in consumers of north eastern Portugal. Food Control, 30(1), 54$421 \quad 57$.

422 Cates, S. C., Kosa, K. M., Karns, S., Godwin, S. L., Speller-Henderson, L., Harrison, R., \& 423 Ann Draughon, F. (2009). Food safety knowledge and practices among older adults: 
identifying causes and solutions for risky behaviors. Journal of Nutrition for the Elderly, 28(2), 112-126.

426

Copenhagen(2015). Complex food chain increases food safety risks. World Health centre/sections/press-releases/2015/03/complex-food-chain-increases-food- safety-risks [Accessed 08 January 2017]

Courtney, S. M., Majowicz, S. E., \&Dubin, J. A. (2016). Food safety knowledge of undergraduate students at a Canadian university: results of an online survey. BMC Public Health, 16(1), 1147.

Cunningham, E.(2015). 5 Tips for Dining Out Safely. Eatright.org. Available at: http://www.eatright.org/resource/homefoodsafety/safety-tips/food-poisoning/5- tips-fordining-out-safely [Accessed on 27 December 2016]

Evans, E. W., \& Redmond, E. C. (2016). Older Adult Consumer Knowledge, Attitudes, and Self-Reported Storage Practices of Ready-to-Eat Food Products and Risks Associated with Listeriosis. Journal of Food Protection, 79(2), 263-272.

Fein, S. B., Lando, A. M., Levy, A. S., Teisl, M. F., \&Noblet, C. (2011). Trends in US consumers' safe handling and consumption of food and their risk perceptions, 1988 through 2010. Journal of Food Protection ${ }^{\circledR}, 74(9)$, 1513-1523.

Food and Drug Administration (FDA) (2016a). Food Safety: It's Especially Important for At-

http://www.fda.gov/Food/FoodborneIllnessContaminants/PeopleAtRisk/ucm352 830.htm\#FS1 [Accessed 19 October 2016]. 
http://www.fda.gov/Food/FoodborneIllnessContaminants/FoodborneIllnessesNeedTo Know/default.htm [Accessed 26 December 2016].

Food Safety Authority of Ireland (FSAI), (2013). Monitoring and surveillance series: Microbiological safety of raw minced beef and beef burgers on retail sale in Ireland (11NS1). pp. 13

Gong, S., Wang, X., Yang, Y., \& Bai, L. (2016). Knowledge of food safety and handling in households: A survey of food handlers in Mainland China. Food Control, 64, 45-53.

Gorman, R., Bloomfield, S., \&Adley, C. C. (2002). A study of cross-contamination of foodborne pathogens in the domestic kitchen in the Republic of Ireland. International Journal of Food Microbiology, 76(1), 143-150.

Hassan, H. F., \&Dimassi, H. (2014). Food safety and handling knowledge and practices of Lebanese university students. Food Control, 40, 127-133.

Health Protection Surveillance Center (HPSC).(2016). Annual Epidemiological Report. ISSN 1649-0436. No. 3.0, pp. 54-77. Dublin, Ireland: HPSC. Healthy Ireland Survey, 2015. Summary of Findings. Available at: http://health.gov.ie/wpcontent/uploads/2015/10/Healthy-Ireland-Survey-2015-Summary-of-Findings.pdf [Accessed 08 January 2016].

IBM Corp. Released (2011). IBM SPSS Statistics for Windows, Version 20.0. Armonk, NY: IBM Corp.

Ismail, F. H., Chik, C. T., Muhammad, R., \&Yusoff, N. M. (2016). Food Safety Knowledge and Personal Hygiene Practices amongst Mobile Food Handlers in Shah Alam, Selangor. Procedia-Social and Behavioral Sciences, 222, 290-298.

Jianu, C., \&Goleţ, I. (2014). Knowledge of food safety and hygiene and personal hygiene practices among meat handlers operating in western Romania. Food Control, 42, 214219. 
473 Langiano, E., Ferrara, M., Lanni, L., Viscardi, V., Abbatecola, A. M., \& De Vito, E. (2012).

474 Food safety at home: knowledge and practices of consumers. Journal of Public $475 \quad$ Health, 20(1), 47-57.

476 Lazou, T., Georgiadis, M., Pentieva, K., McKevitt, A., \&Iossifidou, E. (2012). Food safety 477 knowledge and food-handling practices of Greek university students: A questionnaire$478 \quad$ based survey. Food Control, 28(2), 400-411.

479 McCarthy, M., Brennan, M., Kelly, A. L., Ritson, C., De Boer, M., \& Thompson, N. (2007).

480 Who is at risk and what do they know? Segmenting a population on their food safety 481 knowledge. Food Quality and Preference, 18(2), 205-217.

482 McLeod, S. A. (2014). Questionnaires. Simply Psychology. Available at: $483 \quad$ www.simplypsychology.org/questionnaires.html [Accessed on 01 January 2017]

484 Meysenburg, R., Albrecht, J. A., Litchfield, R., \& Ritter-Gooder, P. K. (2014). Food safety 485 knowledge, practices and beliefs of primary food preparers in families with young 486 children. A mixed methods study. Appetite, 73, 121-131.

487 Mountjoy, B. (2014). A Consumer's Guide to Food Safety Risks. International Food 488 Information Council Foundation. Food Insight, your nutrition and food safety resource. A 489 vailable at: http://www.foodinsight.org/A_Consumer_s_Guide_to_Food_Safety_Risks $490 \quad$ [Accessed on 24 December 2016]

491 National Health Services (NHS).(2014). Beware of Common Household Germs. Available at: http://www.nhs.uk/Livewell/homehygiene/Pages/commonhousehold-germs.aspx

$493 \quad$ [Accessed 1 November 2016].

494 Osaili, T. M., Obeidat, B. A., Jamous, D. O. A., \&Bawadi, H. A. (2011). Food safety 495 knowledge and practices among college female students in north of Jordan. Food $496 \quad$ Control, 22(2), 269-276. 
497 Pappas, P. A., \&DePuy, V. (2004). An overview of non-parametric tests in SAS: when, why, and how. Paper TU04. Duke Clinical Research Institute, Durham, 1-5.

499

Sharif, L., \& Al-Malki, T. (2010). Knowledge, attitude and practice of Taif University students on food poisoning. Food Control, 21(1), 55-60.

Sibanyoni, J. J., Tshabalala, P. A., \&Tabit, F. T. (2017). Food safety knowledge and awareness of food handlers in school feeding programmes in Mpumalanga, South Africa. Food Control, 73, 1397-1406.

504

Simon, M. (2011). Assumptions, limitations and delimitations. Dissertation and scholarly research: Recipes for success. Seattle, WA: Dissertation Success, LLC. Available at www.dissertationrecipes.com.

Stenger, K. M., Ritter-Gooder, P. K., Perry, C., \& Albrecht, J. A. (2014). A mixed methods study of food safety knowledge, practices and beliefs in Hispanic families with young children. Appetite, 83, 194-201.

Sullivan, L. (2016). Nonparametric test. Boston University School of Public Health.

at: http://sphweb.bumc.bu.edu/otlt/MPHModules/BS/BS704_Nonparametric/BS704_Nonparametric2.html [Accessed on 01 January 2017].

514 Uggioni, P. L., \&Salay, E. (2012). Consumer knowledge concerning safe handling practices

515 to prevent microbiological contamination in commercial restaurants and sociodemographic characteristics, Campinas/SP/Brazil. Food Control, 26(2), 331-336.

517 United States Department of Agriculture (USDA), (2016b). Cleanliness Helps Prevent 518 Foodborne Illness. Available at: https:/www.fsis.usda.gov/wps/portal/fsis/topics/food519 safety-education/get-answers/food-safety-fact-sheets/safe-food-handling/cleanlinesshelps-prevent-foodborne-illness/ct_index [Accessed on 26 December 2016]. 
521 United States Department of Agriculture, Food Safety and Inspection (USDA - FSAI), (2016a).

About

$\mathrm{Be}$

Food

Safe.

Available

at:

http://www.fsis.usda.gov/wps/portal/fsis/topics/food-safety-education/teach-others/fsiseducational-campaigns/be-food-safe/about-be-food-safe/about-be-food-safe [Accessed 01 October 2016].

United States Department of Agriculture, Food Safety and Inspection (USDA).(2013). Foodborne Illness: What Consumers Need to Know. Available at:

Webb, M., \&Morancie, A. (2015). Food safety knowledge of foodservice workers at a university campus by education level, experience, and food safety training. Food Control, 50, 259-264.

World Health Organization (WHO)(2014). Advancing Food Safety Initiatives: Strategic Plan for Food Safety Including Foodborne Zoonoses 2013-2022. ISBN \#: 9789241506281. Pp: 7-10. Geneva, Switzerland: WHO.

World Health Organization (WHO), (2015a). WHO's first ever global estimates of foodborne

$$
\text { diseases find children under } 5 \text { account for almost one third of deaths. Available at: }
$$

$$
\text { [Accessed } 08 \text { January 2017]. }
$$

World Health Organization (WHO), (2015b). Food Safety. Available at: http://www.who.int/mediacentre/factsheets/fs399/en/ [Accessed 05 January 2017].

543 Yap, L., Francis, S.L., Shelley, M., Lillehoj, C., Montgomery, D. and Winham, D.M.(2016). 544 Risky Food Handling Practices among Community-Residing Older Adults. The FASEB Journal, 30(1 Supplement), 674-677. 
546 Young, I., \& Waddell, L. (2016). Barriers and Facilitators to Safe Food Handling among

547 Consumers: A Systematic Review and Thematic Synthesis of Qualitative Research $548 \quad$ Studies. PloS one, 11(12), e0167695.

549 
551 Table 1. Sample characteristics

552 Table 2. Respondents knowledge on food storage, pass rate, mean score and standard 553 devastation

554 Table 3. Respondents knowledge on food handling, pass rate, mean score and standard 555 devastation

556 Table 4. Respondents knowledge on usage and maintenance of kitchen facilities, pass rate,

557 mean score and standard devastation

558 Table 5. Respondents knowledge on personal hygiene, pass rate, mean score and standard 559 devastation

560 Table 6. Respondents knowledge on food poisoning, pass rate, mean score and standard

561 devastation

562 Table 7. The relation between the demographic characteristics and knowledge of food safety 563 in homes 
Table 1. Sample characteristics

\begin{tabular}{|c|c|c|c|c|}
\hline Demographic Characteristics & $\mathbf{N}$ & Category & $\begin{array}{c}\text { Responde } \\
\text { nts (n.) }\end{array}$ & $\begin{array}{c}\text { Percentag } \\
\text { e (\%) }\end{array}$ \\
\hline \multirow[t]{3}{*}{ Gender } & \multirow[t]{3}{*}{802} & Male & 372 & 46.4 \\
\hline & & Female & 421 & 51.3 \\
\hline & & Other & 9 & 1.1 \\
\hline \multirow[t]{4}{*}{ Age } & \multirow[t]{4}{*}{805} & $18-25$ & 254 & 31.6 \\
\hline & & $26-35$ & 283 & 35.2 \\
\hline & & $36-50$ & 175 & 21.7 \\
\hline & & 51 and above & 93 & 11.6 \\
\hline \multirow[t]{2}{*}{ Place of Residence } & \multirow[t]{2}{*}{798} & City & 585 & 73.3 \\
\hline & & Countryside & 213 & 26.7 \\
\hline \multirow{4}{*}{$\begin{array}{l}\text { Per Capita Annual income } \\
\text { (Euro's) }\end{array}$} & \multirow[t]{4}{*}{785} & Below 30,000 & 463 & 59.0 \\
\hline & & $30,000-60,000$ & 223 & 28.4 \\
\hline & & $60,001-100,000$ & 74 & 9.4 \\
\hline & & 100,000 and above & 25 & 3.2 \\
\hline \multirow[t]{4}{*}{ Educational Level } & \multirow[t]{4}{*}{801} & University and Above & 581 & 72.5 \\
\hline & & $\begin{array}{l}\text { Leaving Cert - Senior } \\
\text { Secondary }\end{array}$ & 147 & 18.4 \\
\hline & & Junior Cert - Junior Secondary & 47 & 5.9 \\
\hline & & No qualification & 26 & 3.2 \\
\hline \multirow[t]{4}{*}{ Marital Status } & \multirow[t]{4}{*}{803} & Unmarried & 447 & 55.7 \\
\hline & & Married without children & 84 & 10.5 \\
\hline & & Married with children & 218 & 27.1 \\
\hline & & Other & 54 & 6.7 \\
\hline
\end{tabular}

Note: exchange rate was 1 euro equals 1.05 US dollars by the end of 2016. 
Table 2. Respondents' knowledge on food storage, pass rate, mean score and standard devastation

\begin{tabular}{|c|c|c|c|c|}
\hline Questions & $\mathbf{N}$ & Category & $\begin{array}{l}\text { Respondents } \\
\text { (n.) }\end{array}$ & $\begin{array}{c}\text { Percentage } \\
(\%)\end{array}$ \\
\hline \multirow[t]{4}{*}{$\begin{array}{l}\text { 1. How should chunks of raw } \\
\text { meat be stored? }\end{array}$} & \multirow[t]{4}{*}{816} & $\begin{array}{l}\text { Store it directly in the } \\
\text { refrigerator }\end{array}$ & 315 & 38.6 \\
\hline & & $\begin{array}{l}\text { Slice it into smaller pieces, } \\
\text { then store them in the } \\
\text { refrigerator }\end{array}$ & 56 & 6.9 \\
\hline & & $\begin{array}{l}\text { Slice into smaller pieces, } \\
\text { seal and store them in the } \\
\text { refrigerator }\end{array}$ & 392 & 48.0 \\
\hline & & Store it in a cool place & 53 & 6.5 \\
\hline \multirow{4}{*}{$\begin{array}{l}\text { 2. Can bacteria in food be } \\
\text { killed by freezing at }-18^{\circ} \mathrm{C} \text { ? }\end{array}$} & \multirow[t]{4}{*}{818} & Yes, totally & 115 & 14.1 \\
\hline & & Yes, partly & 306 & 37.4 \\
\hline & & Not at all & 234 & 28.6 \\
\hline & & Do not know & 163 & 19.9 \\
\hline \multirow{4}{*}{$\begin{array}{l}\text { 3. When is the best time to } \\
\text { purchase frozen food when } \\
\text { shopping? }\end{array}$} & \multirow[t]{4}{*}{818} & $\begin{array}{l}\text { At the beginning of the } \\
\text { shopping time }\end{array}$ & 49 & 6.0 \\
\hline & & $\begin{array}{l}\text { At the end of the shopping } \\
\text { time }\end{array}$ & 639 & 78.1 \\
\hline & & Whenever, does not matter & 101 & 12.3 \\
\hline & & Do not know & 29 & 3.5 \\
\hline \multirow{4}{*}{$\begin{array}{l}\text { 4. What is the optimal } \\
\text { temperature for storing frozen } \\
\text { food? }\end{array}$} & \multirow[t]{4}{*}{810} & +2 & 63 & 7.8 \\
\hline & & 2 & 117 & 14.4 \\
\hline & & $-18^{\circ} \mathrm{C}$ or Below & 516 & 63.7 \\
\hline & & Do not know & 114 & 14.1 \\
\hline \multirow[t]{4}{*}{$\begin{array}{l}\text { 5. What should be done with } \\
\text { freshly prepared food that will } \\
\text { be consumed } 3 \text { hours later? }\end{array}$} & \multirow[t]{4}{*}{808} & $\begin{array}{l}\text { Put in the refrigerator, } \\
\text { then reheat when ready to } \\
\text { eat }\end{array}$ & 526 & 65.1 \\
\hline & & $\begin{array}{l}\text { Put it in the cupboard, then } \\
\text { reheat when ready to eat }\end{array}$ & 86 & 10.6 \\
\hline & & $\begin{array}{l}\text { Put it in the microwave } \\
\text { oven }\end{array}$ & 57 & 7.1 \\
\hline & & $\begin{array}{l}\text { Cover it and put it on the } \\
\text { cabinet }\end{array}$ & 139 & 17.2 \\
\hline \multirow{4}{*}{$\begin{array}{l}\text { 6. Should thawed meat be } \\
\text { frozen for later use? }\end{array}$} & \multirow[t]{4}{*}{805} & Yes & 96 & 11.9 \\
\hline & & No & 544 & 67.6 \\
\hline & & Maybe & 72 & 8.9 \\
\hline & & Do not know & 93 & 11.6 \\
\hline \multirow{2}{*}{$\begin{array}{l}\text { Total Score } \\
\text { Pass rate }(\%) \\
\text { Mean score } \pm \text { standard } \\
\text { deviation }\end{array}$} & \multirow{2}{*}{ 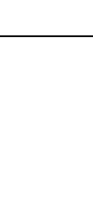 } & & 430 & 52.8 \\
\hline & & & & $3.5 \pm 1.4$ \\
\hline
\end{tabular}


Table 3. Respondents' knowledge on food handling, pass rate, mean score and standard devastation

\begin{tabular}{|c|c|c|c|c|}
\hline Questions & $\mathbf{N}$ & Category & $\begin{array}{l}\text { Respondents } \\
\text { (n.) }\end{array}$ & $\begin{array}{l}\text { Percent } \\
(\%)\end{array}$ \\
\hline \multirow{4}{*}{$\begin{array}{l}\text { 7. How should vegetables and } \\
\text { fruits be washed? }\end{array}$} & \multirow[t]{4}{*}{805} & Soak in detergent & 23 & 2.9 \\
\hline & & Wash with hot water & 100 & 12.4 \\
\hline & & $\begin{array}{l}\text { Wash with running cold } \\
\text { water }\end{array}$ & 532 & 66.1 \\
\hline & & $\begin{array}{l}\text { Soak in cold water, then } \\
\text { wash }\end{array}$ & 150 & 18.6 \\
\hline \multirow{4}{*}{$\begin{array}{l}\text { 8. Of the following, which is } \\
\text { the least safe way to thaw raw } \\
\text { meat? }\end{array}$} & \multirow[t]{4}{*}{797} & In refrigerator & 113 & 14.2 \\
\hline & & On chopping board & 347 & 43.5 \\
\hline & & In microwave oven & 218 & 27.4 \\
\hline & & $\begin{array}{l}\text { In cold water in sealed } \\
\text { package }\end{array}$ & 119 & 14.9 \\
\hline \multirow{4}{*}{$\begin{array}{l}\text { 9. Of the following, which is } \\
\text { the correct way to heat } \\
\text { leftovers? }\end{array}$} & \multirow[t]{4}{*}{805} & $\begin{array}{l}\text { Heat it to the temperature } \\
\text { you prefer }\end{array}$ & 235 & 29.2 \\
\hline & & $\begin{array}{l}\text { Reheat is not necessary if } \\
\text { it is during the summer }\end{array}$ & 42 & 5.2 \\
\hline & & $\begin{array}{l}\text { Heat until they are } \\
\text { boiling }\end{array}$ & 428 & 53.2 \\
\hline & & Do not know & 100 & 12.4 \\
\hline \multirow{4}{*}{$\begin{array}{l}\text { 10. What should be done if the } \\
\text { leftovers are still not eaten } \\
\text { completely? }\end{array}$} & \multirow[t]{4}{*}{805} & \begin{tabular}{|l|} 
Discard them \\
immediately \\
\end{tabular} & 399 & 49.6 \\
\hline & & $\begin{array}{l}\text { Put in the refrigerator } \\
\text { immediately and reheat } \\
\text { before consuming }\end{array}$ & 293 & 36.4 \\
\hline & & $\begin{array}{l}\text { Store in kitchen and reheat } \\
\text { before consuming }\end{array}$ & 54 & 6.7 \\
\hline & & $\begin{array}{l}\text { As long as they smell } \\
\text { good, eat them }\end{array}$ & 59 & 7.3 \\
\hline \multirow{2}{*}{$\begin{array}{l}\text { Total Score } \\
\text { Pass rate }(\%) \\
\text { Mean score } \pm \text { standard } \\
\text { deviation }\end{array}$} & & & 89 & 10.8 \\
\hline & & & & $2.1 \pm 1.1$ \\
\hline
\end{tabular}


Table 4. Respondents knowledge on usage and maintenance of kitchen facilities, pass rate, mean score and standard devastation

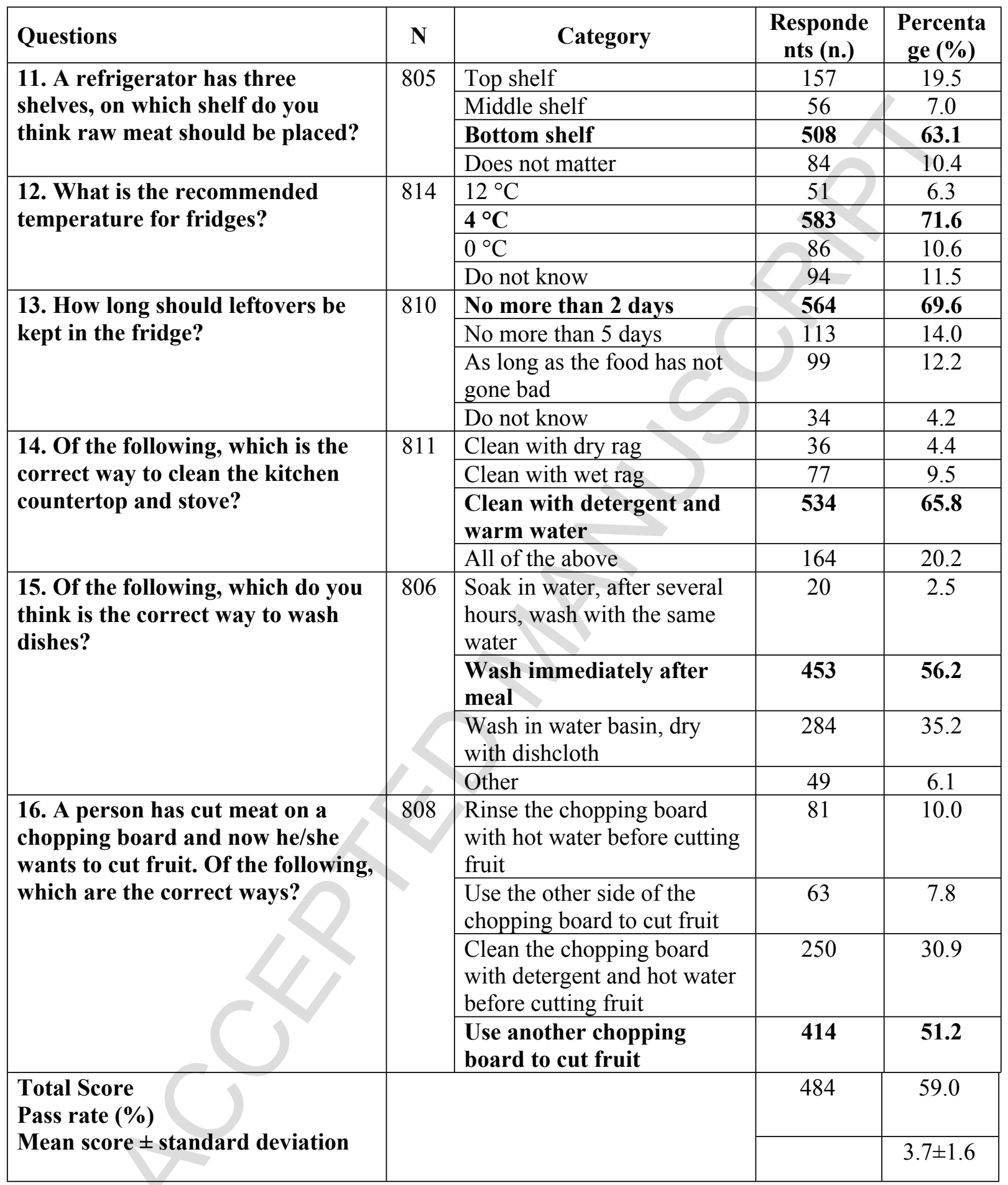


Table 5. Respondents knowledge on personal hygiene, pass rate, mean score and standard devastation

\begin{tabular}{|c|c|c|c|c|}
\hline Questions & $\mathbf{N}$ & Category & $\begin{array}{c}\text { Respondents } \\
\text { (n.) }\end{array}$ & $\begin{array}{c}\text { Percentage } \\
(\%)\end{array}$ \\
\hline \multirow{4}{*}{$\begin{array}{l}\text { 17. Is it safe to handle food if a } \\
\text { person has a wound on the back } \\
\text { of his/her hand? }\end{array}$} & \multirow[t]{4}{*}{805} & $\begin{array}{l}\text { Yes, as long as the wound is } \\
\text { not infected }\end{array}$ & 70 & 8.7 \\
\hline & & $\begin{array}{l}\text { Yes, as long as the wound } \\
\text { has a bandage on it }\end{array}$ & 185 & 23.0 \\
\hline & & $\begin{array}{l}\text { Yes, as long as gloves are } \\
\text { worn }\end{array}$ & 373 & 46.3 \\
\hline & & Not at all & 177 & 22.0 \\
\hline \multirow[t]{4}{*}{$\begin{array}{l}\text { 18. Of the following, which is the } \\
\text { correct way to wash hands? }\end{array}$} & \multirow[t]{4}{*}{810} & $\begin{array}{l}\text { Wash with running cold } \\
\text { water, wipe dry }\end{array}$ & 32 & 4.0 \\
\hline & & $\begin{array}{l}\text { Wash with running warm } \\
\text { water, wipe dry }\end{array}$ & 64 & 7.9 \\
\hline & & $\begin{array}{l}\text { Wet hands with cold water } \\
\text { in a basin, use soap and then } \\
\text { wash hands with cold water } \\
\text { in the basin, wipe dry }\end{array}$ & 98 & 12.1 \\
\hline & & $\begin{array}{l}\text { Wet hands with running } \\
\text { warm water, use soap and } \\
\text { then wash with running } \\
\text { warm water, wipe dry }\end{array}$ & 616 & 76.0 \\
\hline \multirow{4}{*}{$\begin{array}{l}\text { 19. Of the following, which is the } \\
\text { correct way to wash hands after } \\
\text { handling raw meat? }\end{array}$} & \multirow[t]{4}{*}{806} & Wipe with towel & 21 & 2.6 \\
\hline & & $\begin{array}{l}\text { Wash with cold water, wipe } \\
\text { dry }\end{array}$ & 41 & 5.1 \\
\hline & & $\begin{array}{l}\text { Wash with warm water, } \\
\text { wipe dry }\end{array}$ & 59 & 7.3 \\
\hline & & $\begin{array}{l}\text { Wash with soap and warm } \\
\text { water, wipe dry }\end{array}$ & 685 & 85.0 \\
\hline \multirow{4}{*}{$\begin{array}{l}\text { 20. After touching which of the } \\
\text { following should a person wash } \\
\text { his/her hands during the course of } \\
\text { preparing food? }\end{array}$} & \multirow[t]{4}{*}{800} & Face & 30 & 3.8 \\
\hline & & $\begin{array}{l}\text { Pimple on the surface of } \\
\text { skin }\end{array}$ & 123 & 15.4 \\
\hline & & Clothes & 42 & 5.3 \\
\hline & & All of the above & 605 & 75.6 \\
\hline \multirow{4}{*}{$\begin{array}{l}\text { 21. People with which of the } \\
\text { following symptoms should not } \\
\text { cook for others? }\end{array}$} & \multirow[t]{4}{*}{801} & $\begin{array}{l}\text { Diarrhea, Fever, Sore } \\
\text { throat or Flu }\end{array}$ & 607 & 75.8 \\
\hline & & Skin allergies & 96 & 12.0 \\
\hline & & AIDS & 78 & 9.7 \\
\hline & & Headache & 20 & 2.5 \\
\hline \multirow{2}{*}{$\begin{array}{l}\text { Total Score } \\
\text { Pass rate }(\%) \\
\text { Mean score } \pm \text { standard deviation }\end{array}$} & & & 501 & 61.0 \\
\hline & & & & $3.5 \pm 1.4$ \\
\hline
\end{tabular}

The correct answer for each question is highlighted in bold 
Table 6. Respondents knowledge on food poisoning, pass rate, mean score and standard devastation

\begin{tabular}{|c|c|c|c|c|}
\hline Questions & $\mathbf{N}$ & Category & $\begin{array}{l}\text { Respondents } \\
\text { (n.) }\end{array}$ & $\begin{array}{c}\text { Percentage } \\
(\%)\end{array}$ \\
\hline \multirow{4}{*}{$\begin{array}{l}\text { 22. Which is the most } \\
\text { important for preventing food } \\
\text { poisoning? }\end{array}$} & \multirow[t]{4}{*}{799} & $\begin{array}{l}\text { Spray the kitchen with } \\
\text { insecticides weekly }\end{array}$ & 41 & 5.1 \\
\hline & & Avoid eating leftovers & 138 & 17.3 \\
\hline & & $\begin{array}{l}\text { Keep food refrigerated } \\
\text { until it is time to serve } \\
\text { them }\end{array}$ & 346 & 43.3 \\
\hline & & $\begin{array}{l}\text { Use detergent to disinfect } \\
\text { kitchen countertop and } \\
\text { stove weekly }\end{array}$ & 274 & 34.3 \\
\hline \multirow{4}{*}{$\begin{array}{l}\text { 23. How to prevent salmonella } \\
\text { poisoning? }\end{array}$} & \multirow[t]{4}{*}{803} & Fully heat food & 554 & 69.0 \\
\hline & & $\begin{array}{l}\text { Wash food with very hot } \\
\text { water }\end{array}$ & 50 & 6.2 \\
\hline & & $\begin{array}{l}\text { Freeze food for more than } \\
3 \text { days }\end{array}$ & 48 & 6.0 \\
\hline & & Do not know & 151 & 18.8 \\
\hline \multirow{4}{*}{$\begin{array}{l}\text { 24. Which of the following is } \\
\text { most likely to become } \\
\text { contaminated with } \\
\text { Escherichia Coli }(\text { E. coli)? }\end{array}$} & \multirow[t]{4}{*}{802} & Tap water & 139 & 17.3 \\
\hline & & Raw pork or beef & 423 & 52.7 \\
\hline & & Raw vegetables & 90 & 11.2 \\
\hline & & Do not know & 150 & 18.7 \\
\hline \multirow{4}{*}{$\begin{array}{l}\text { 25. Which of the following is } \\
\text { most likely to become } \\
\text { contaminated with Listeria? }\end{array}$} & \multirow[t]{4}{*}{801} & $\begin{array}{l}\text { Raw or uncooked meat } \\
\text { and eggs }\end{array}$ & 361 & 45.1 \\
\hline & & $\begin{array}{l}\text { Meat sauce from the } \\
\text { deli }\end{array}$ & 81 & 10.1 \\
\hline & & Raw vegetables & 85 & 10.6 \\
\hline & & Do not know & 274 & 34.2 \\
\hline \multirow{4}{*}{$\begin{array}{l}\text { 26. You can get food } \\
\text { poisoning from eating which } \\
\text { of the following? }\end{array}$} & \multirow[t]{4}{*}{801} & $\begin{array}{l}\text { Fruits taken out of the } \\
\text { refrigerator immediately }\end{array}$ & 17 & 2.1 \\
\hline & & Unheated canned food & 88 & 11.0 \\
\hline & & $\begin{array}{l}\text { Raw or undercooked } \\
\text { beef and eggs }\end{array}$ & 597 & 74.5 \\
\hline & & Other & 99 & 12.4 \\
\hline \multirow{2}{*}{$\begin{array}{l}\text { Total Score } \\
\text { Pass rate }(\%) \\
\text { Mean score } \pm \text { standard } \\
\text { deviation }\end{array}$} & & 165 & 20.1 \\
\hline & & & & $2.4 \pm 1.2$ \\
\hline
\end{tabular}


Table 7. The relation between the demographic characteristics and knowledge of food safety in homes

\begin{tabular}{|c|c|c|c|c|c|}
\hline Variables & $\mathrm{N}$ & $\begin{array}{l}\text { Pass rate } \\
(\%)\end{array}$ & P-value & $\begin{array}{l}\text { Mean } \\
\text { score }\end{array}$ & P-value \\
\hline $\begin{array}{r}\text { Gender } \\
\text { Male }\end{array}$ & \multirow[t]{3}{*}{802} & 39.7 & \multirow[t]{3}{*}{0.000} & 14.4 & \multirow[t]{3}{*}{0.000} \\
\hline Female & & 59.8 & & 16.4 & \\
\hline Other & & 0.6 & & 11.3 & \\
\hline $\begin{array}{l}\text { Age } \\
\qquad 18-25\end{array}$ & \multirow[t]{4}{*}{805} & 29.2 & \multirow[t]{4}{*}{0.000} & 14.8 & \multirow[t]{4}{*}{0.000} \\
\hline $26-35$ & & 33.0 & & 14.8 & \\
\hline $36-50$ & & 23.6 & & 16.4 & \\
\hline 51 and above & & 14.2 & & 17.0 & \\
\hline $\begin{array}{l}\text { Place of Residence } \\
\text { City }\end{array}$ & \multirow[t]{2}{*}{798} & 69.1 & \multirow[t]{2}{*}{0.000} & 15.0 & \multirow[t]{2}{*}{0.000} \\
\hline Countryside & & 30.9 & & 16.7 & \\
\hline $\begin{array}{l}\text { Per Capita Annual income (Euro's) } \\
\text { Below 30,000 }\end{array}$ & \multirow[t]{4}{*}{785} & 58.9 & & 15.2 & \multirow[t]{4}{*}{0.130} \\
\hline $30,000-60,000$ & & 29.6 & & 16.1 & \\
\hline $60,001-100,000$ & & 8.9 & & 15.0 & \\
\hline 100,000 and above & & 2.6 & & 14.7 & \\
\hline $\begin{array}{l}\text { Educational Level } \\
\text { University and Above }\end{array}$ & \multirow[t]{4}{*}{801} & 74.2 & \multirow[t]{4}{*}{0.000} & 15.7 & \multirow[t]{4}{*}{0.000} \\
\hline Leaving Cert - Senior Secondary & & 20.8 & & 16.2 & \\
\hline Junior Cert - Junior Secondary & & 3.3 & & 11.9 & \\
\hline No qualification & & 1.7 & & 11.0 & \\
\hline $\begin{array}{l}\text { Marital Status } \\
\text { Unmarried }\end{array}$ & \multirow[t]{4}{*}{803} & 53.3 & \multirow[t]{4}{*}{0.000} & 15.0 & \multirow[t]{4}{*}{0.000} \\
\hline Married without children & & 7.8 & & 13.2 & \\
\hline Married with children & & 31.1 & & 16.7 & \\
\hline Other & & 7.8 & & 16.7 & \\
\hline
\end{tabular}

Note: exchange rate was 1 euro equals 1.05 US dollars by the end of 2016.

Pass rates tested using Chi-square $\left(X^{2}\right)$ Test

Mean scores tested using Manne-Whitney $U$ and Kruskal-Wallis Tests 